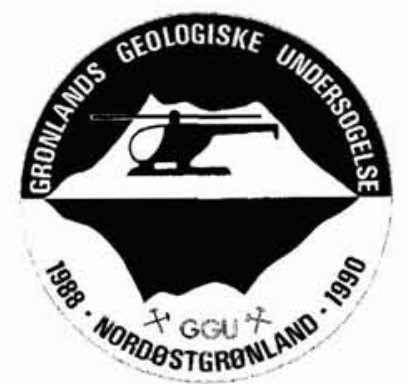

\title{
Eclogites and related high-pressure rocks from North-East Greenland
}

\author{
Jane A. Gilotti
}

\begin{abstract}
Eclogite, garnet clinopyroxenite, garnet websterite and websterite bodies were discovered within the Skærfjorden gneiss complex during recent mapping in North-East Greenland. These eclogitic pods extend from Danmarkshavn (c. $\left.76^{\circ} 40^{\prime} \mathrm{N}\right)$ to the northern limit of the area mapped $\left(78^{\circ} \mathrm{N}\right)$, and attest to widespread high-pressure metamorphism. Eclogites with the assemblage omphacite + garnet \pm quartz \pm rutile are common. The protoliths of some of the eclogites were xenoliths within the precursor batholiths to the gneisses. Field relations, regional correlations and preliminary geochronology indicate that the eclogite facies metamorphism is Caledonian. The eclogites formed at minimum pressures between 10-15 kilobars and temperatures between $600-900^{\circ} \mathrm{C}$, and hence are the medium-temperature type typically formed in overthickened crust during continent collision.
\end{abstract}

\section{J.A. G., Geological Survey, New York State Museum, Albany, NY 12230, U.S.A.}

Eclogites sensu stricto are metamorphic rocks of basaltic composition that are primarily composed of $\mathrm{Mg}$-rich garnet and omphacite not in equilibrium with plagioclase (Carswell, 1990). Eclogites can form over a broad temperature range but only at high pressures ( $\mathrm{P}>10 \mathrm{kbar}$ ). As such, they provide information on the tectonic environment of rocks which have experienced metamorphism at great depths in the crust. Eclogites sensu stricto and other high-pressure rocks were discovered between latitudes $77^{\circ}$ and $78^{\circ} \mathrm{N}$ (Fig. 1) during the final field season of the Geological Survey of Greenland's 19881990 North-East Greenland expeditions (Friderichsen et al., 1991; Gilotti, 1993). Additional eclogite localities were found in the vicinity of the Danmarkshavn weather station $\left(\sim 76^{\circ} 40^{\prime} \mathrm{N}\right)$ by the author during two weeks of field work in July 1992 (Fig. 2), a confirmation of field observations of "bright green eclogite" (Bronner, 1948) made during Louise A. Boyd's 1937 expedition.

The eclogitic rocks are composed of a variety of lithologies. The most common are eclogites sensu stricto, garnet clinopyroxenites, garnet websterites, and websterites (Figs $1 \& 2$ ). The eclogite facies rocks are associated with both orthogneisses and paragneisses as isolated to abundant lenticular pods, 1 to $30 \mathrm{~m}$ long, and as strings of tabular blocks. Eclogites forming distinct lenses surrounded by gneiss have been referred to as Group B eclogites in the Coleman et al. (1965) classification, or as 'country rock' and 'external' eclogites in the Western Gneiss Region of Norway (Griffin et al. 1985; Smith, 1988).

The North-East Greenland occurrences are the first true eclogites described from Greenland to date. Over the years, however, eclogitic rocks have been mentioned in the Greenland literature. Early workers recognised garnet-clinopyroxene rocks in Liverpool Land, East Greenland (Krank, 1935; Sahlstein, 1935). These rocks were cited by Backlund (1936) to support his theory on the metamorphic origin of eclogites. Subsequent work in Liverpool Land (Coe \& Cheeney, 1972; Cheeney, 1985) has not revealed any omphacite; the highest jadeite content reported in clinopyroxene there is $10 \%$. However, an inferred supersilicic clinopyroxene in a sample from Rendeelven (Smith \& Cheeney, 1980; Smith, 1988) and a chromite-garnet lherzolite from Tværdalen (Smith \& Cheeney, 1981) indicate a high-pressure metamorphic event. The nature, extent, and timing of high-pressure metamorphism in Liverpool Land is currently unknown, and deserves further examination. High-pressure granulites of unknown age have also been described from Payers Land $\left(74^{\circ} 30^{\prime} \mathrm{N}\right.$ to $75^{\circ} \mathrm{N}$ ), East Greenland (Larsen, 1981).

Possible retrograde eclogites have been reported from the Ammassalik region of South-East Greenland (Wright et al., 1973). Metabasalt dykes containing garnet and clinopyroxene with coarse, globular symplectitic intergrowths of diopside and plagioclase have been interpreted as relict eclogites (Nutman \& Friend, 1989; Messiga et al., 1990). Kalsbeek and Taylor (1989) have obtained a garnet-clinopyroxene-whole rock Sm-Nd mineral isochron of $1817 \pm 22 \mathrm{Ma}$ from one of these dykes.

A large $\left(\sim 10000 \mathrm{~km}^{2}\right)$, medium-temperature eclogite province in the North-East Greenland Caledonides has been documented by Gilotti (1993). The extent of this 


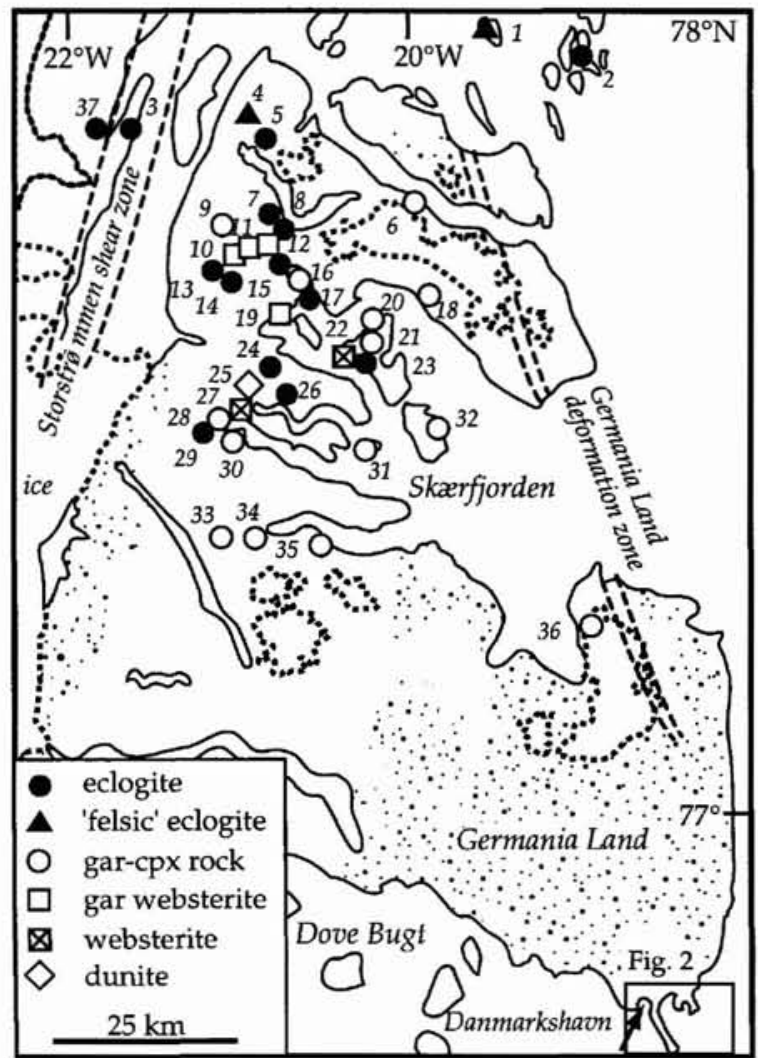

Fig. 1. Map showing all sample localities of eclogites and related rocks in North-East Greenland, modified from Gilotti (1993). Corresponding GGU sample numbers for each locality are given in Table 1. Stippled areas are covered by Quaternary deposits.

province, particularly to the north, is not known. Eclogitic pods have been observed west of the Storstrømmen shear zone (Gilotti, 1993; Strachan et al., 1991), and as far south as Edvard $\varnothing\left(\sim 76^{\circ} 35^{\prime} \mathrm{N}\right)$ in Dove Bugt (Chadwick et al., 1990). Earlier reports of eclogitic rocks in the southern part of the region can be found in Bronner (1948) and Wyllie (1957). This paper aims to illustrate and summarise the general field relations and petrological aspects of the eclogites and related high-pressure rocks in North-East Greenland. Detailed studies on the metamorphic history, geochemistry, and geochronology are in progress.

\section{Field relationships}

The eclogites and other high-pressure garnet-pyroxene rocks are found as lenses within a regionally extensive, polyphase, medium to high-grade orthogneiss complex (Fig. 1). The bedrock geology of the gneiss complex in the study area is described by Friderichsen et al. (1991), Strachan et al. (1991), and Hull et al. (1994). Paragneiss layers, including metapelite, quartzite, marble and calcsilicate lithologies, are folded together with more voluminous, predominantly quartzofeldspathic orthogneisses. The gneiss complex is cut by later intrusive suites, most notably K-feldspar metaporphyries (e.g. Fig. 3). Both the gneisses and the later metagranitoids were subsequently intruded by metadolerite dyke swarms. The gneisses are cut by two sub-vertical mylonite zones (Fig. 1): the NNEstriking Storstrømmen shear zone (Holdsworth \& Strachan, 1991; Strachan et al., 1992) and the NNW-striking Germania Land deformation zone (Hull \& Gilotti, 1994). Eclogites are found on all sides of these mylonite zones in the study area.

The distribution of eclogitic rocks shown in Figure 1 does not reflect the true distribution of eclogitic rocks in the region, but rather the propensity of different field teams for sampling these rocks, and the amount of time spent in an area. Most of the eastern part of the study area shown in Figure 1 was mapped only via helicopter reconnaissance. In addition, the abundance of pods varies greatly within the region. In any given square kilometre, there can be a few isolated bodies or literally hundreds of small ( $<5 \mathrm{~m}$ long), eclogitic pods. The latter scenario is often the case when eclogite-rich gneisses with shallow, south-west dip slopes are exposed. In the Danmarkshavn area (Fig. 2), strike-parallel layers with abundant eclogitic pods alternate with eclogite poor regions within the highly deformed, sub-vertical, NNW-striking gneisses. One such prominent string of tabular garnet-pyroxenite

Table 1. GGU Sample numbers for localities shown in Figure 1

\begin{tabular}{|c|c|c|c|}
\hline Loc. & GGU No & Loc. & GGU No \\
\hline 1 & 363168 & 19 & 363017 \\
\hline 2 & 363149 & 20 & 361904 \\
\hline 3 & $363049-050$ & 21 & $363003-004$ \\
\hline 4 & 363107 & 22 & 363007 \\
\hline 5 & 363105 & 23 & 361901 \\
\hline 6 & 363032 & & 363001 \\
\hline 7 & 363039 & 24 & $363055-056$ \\
\hline 8 & 363038 & 25 & 364092 \\
\hline 9 & 363026 & 26 & 363054 \\
\hline 10 & 363027 & 27 & $363063-064$ \\
\hline 11 & 363020 & 28 & $364565-566$ \\
\hline 12 & 363019 & 29 & 364544 \\
\hline 13 & 363028 & 30 & 364563 \\
\hline 14 & 363029 & 31 & 364533 \\
\hline \multirow[t]{2}{*}{15} & $363015-016$ & 32 & $363059-060$ \\
\hline & 363183 & 33 & 364504 \\
\hline 16 & 363010 & 34 & 364501 \\
\hline 17 & $363012-013$ & 35 & 364579 \\
\hline \multirow[t]{2}{*}{18} & 363008 & 36 & 364520 \\
\hline & & 37 & 347538 \\
\hline
\end{tabular}




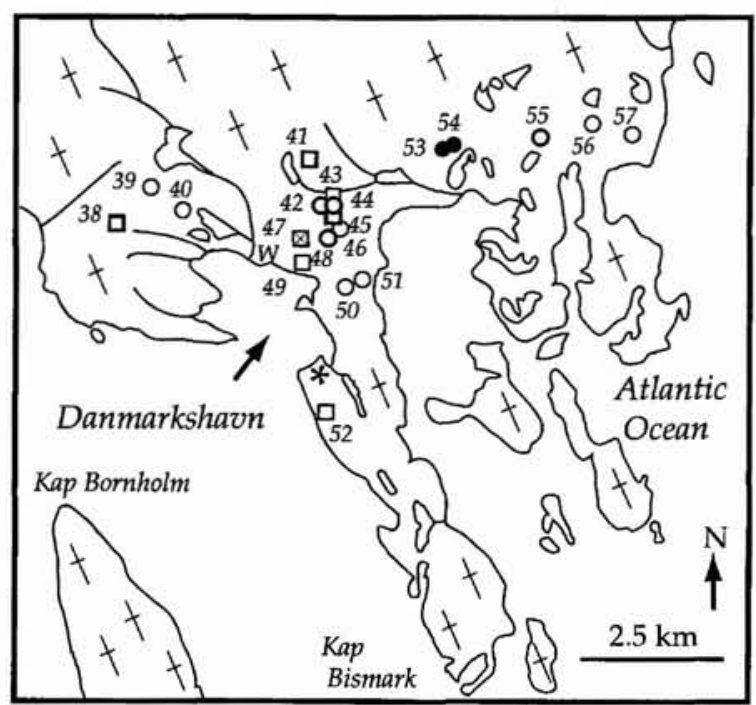

Fig. 2. Sample localities of eclogites and related rocks in the Danmarkshavn area. Symbols as in Figure 1. Table 2 gives GGU sample numbers for each locality. $\mathrm{W}=$ weather station; * = dating locality of Steiger et al. (1976).

blocks can be found on Termometerfjeld, about $1 \mathrm{~km}$ north-east of the Danmarkshavn weather station.

The internal structure and composition of these eclogitic bodies is quite varied. A few of the pods are massive and unfoliated with contacts oblique to the surrounding gneissosity (Fig. 4a). More commonly, the lenses contain a foliation that is sub-parallel to that in the host gneisses (Fig. 4b). Some pods are homogeneous, whereas others are distinctly layered. The layering is defined by changes in the modal amounts of garnet and clinopyroxene, grain size variations, or the intercalation of distinct lithologies (e.g. garnet clinopyroxenites together with garnet websterites). In most cases, the layering probably reflects primary differences in composition. In a few cases, the internal layering is complexly folded. At locality 15 (Fig. 1), for example, a $1 \mathrm{~cm}$ thick garnet-rich layer is isoclinally folded within a relatively planar, $0.5 \mathrm{~m}$ thick eclogite band. The eclogitic rocks have been variably overprinted by amphibolite facies assemblages. In many cases, the retrogression is nearly pervasive, and garnet amphibolites with just a trace of clinopyroxene are preserved. Even lenses with well-preserved, high-pressure assemblages have retrograde rims a few centimetres to one metre thick.

The gneiss complex contains low-strain lenses up to a kilometre wide (Hull et al., 1994). These macroscopic augen are important elements of many gneiss complexes (cf. Sørensen, 1983; Johansson, 1986) because primary structural elements and cross-cutting relationships can survive low strain deformation. The orthogneisses in these augen preserve relics of an igneous texture, and range from granitic to granodioritic in composition. These granitoids contain mafic xenoliths that are locally abundant enough to form an agmatite. Large tracts of agmatite are observed in the Skærfjorden area; one particularly impressive section is exposed on a $600 \mathrm{~m}$ high cliff on the south shore of C. F. Mourier Fjord (Haller, 1956; Hull et al., 1994). Some, but not all, of the xenoliths are now eclogites and pyroxenites (cf. Fig. 3 in Friderichsen et al., 1991); a few of the blocks have been intruded by the granitoids. Similar field relationships have been described for eclogite blocks from the Argentera Massif of the western Alps (Mottana, 1972) and from the D'Entrecasteaux Islands of Papua New Guinea (Hill \& Baldwin, 1993).

In high strain zones, the pronounced foliation in the gneisses envelops the eclogitic bodies and their protolith is more uncertain. Some of these bodies were probably also xenoliths. Figure 3 illustrates a small websterite pod lying with its long axis parallel to the surrounding, strongly deformed, planar banded orthogneisses. These gneisses are clearly truncated by a less deformed sheet of megacrystic metagranitoid. The concordance between the websterite body and the straight gneisses suggests that the websterite was a component of the gneisses before the intrusion of the granitic sheet. The bodies of eclogitic rocks that occur as continuous strings of blocky pods may be better explained as boudin of dykes or sills that intruded the host rocks prior to the gneiss forming event but before the intrusion of the granitoid sheets. A xenolith origin is favoured for the pod in Figure 3 due to its isolated position and composition.

Metadolerite dykes that clearly truncate the orthogneisses and the later metagranitoid sheets are widespread throughout the study area. Diopside $\left(\mathrm{Jd}_{5}\right)$-andesine symplectites have been identified in one of these dykes (Gilotti, 1993) near locality 5 in Figure 1. The wormy,

Table 2. GGU Sample numbers for localities shown in Figure 2

\begin{tabular}{llll}
\hline Loc. & GGU No & Loc. & GGU No \\
\hline 38 & $407513-514$ & 48 & 365360 \\
& 407542 & 49 & 407506 \\
39 & $407538-539$ & 50 & 407502 \\
40 & $407509-510$ & 51 & $407503-504$ \\
41 & 407519 & 52 & 365361 \\
42 & 407536 & 53 & $407564-567$ \\
43 & $407532-533$ & 54 & $407555-563$ \\
44 & 407534 & & 407573 \\
45 & $407530-531$ & 55 & $407553-554$ \\
46 & 407517 & 56 & 407551 \\
47 & $407520-525$ & 57 & 407550 \\
\hline
\end{tabular}



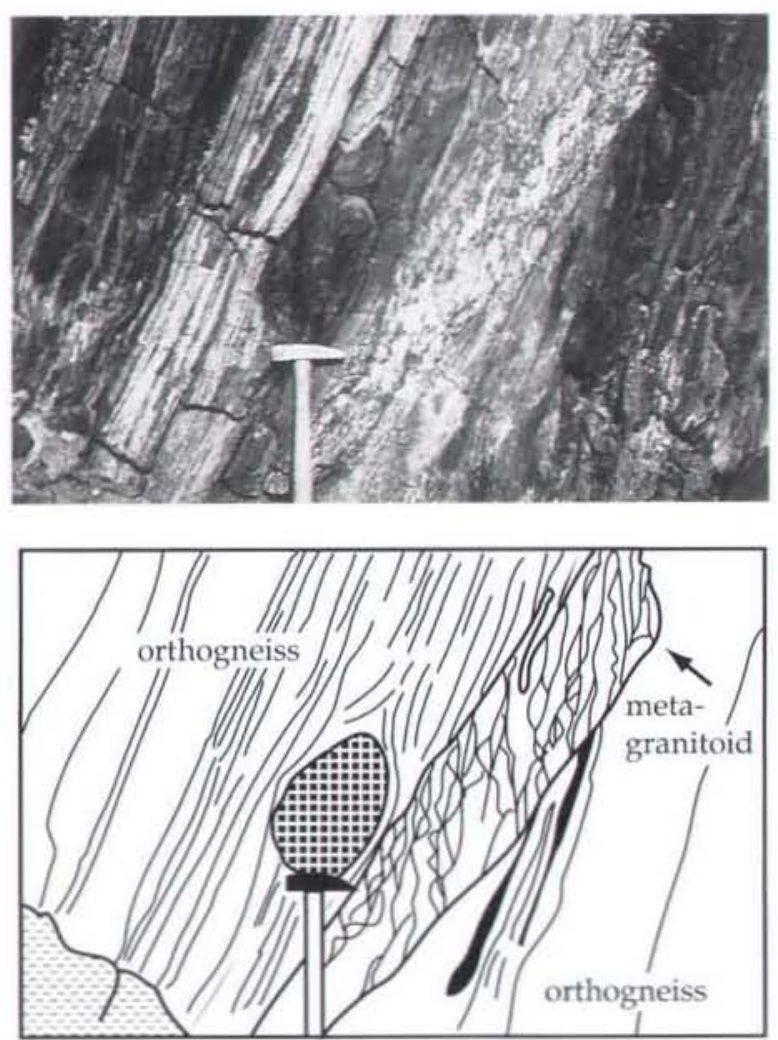

Fig. 3. Photograph and sketch of locality 12 in Figure 1. A small. garnet websterite pod (above hammer) is enveloped by straight orthogneisses which are cut by a sheet of porphyritic metagranitoid. The metagranitoid has a relatively steep, anastomosing schistosity. The dark surfaces of the gneiss outcrop are stained; on fresh surfaces the gneisses are various shades of grey.

globular symplectites are similar to those described in dykes from the Ammassalik region (Nutman \& Friend, 1989; Messiga et al., 1990), and could be interpreted as decompression textures from a high-pressure metamorphism. Other cross-cutting dykes, particularly those in the Danmarkshavn area, contain the granulite facies assemblage garnet + diopside + quartz + plagioclase. The dykes have clearly experienced high-grade Caledonian metamorphism; however, no eclogite sensu stricto has been found within the dykes so far.

No eclogite facies assemblages (e.g. jadeite + quartz) have been discovered in the quartzofeldspathic gneisses to date. The gneisses contain relict granulite facies assemblages of gamet + clinopyroxene + plagioclase + quartz that have escaped the pervasive amphibolite facies overprint (see Fig. 5 in Hull \& Gilotti, 1994). Garnet + kyanite + plagioclase + quartz + biotite paragneisses. which attest to fairly high pressures, lie adjacent to some eclogitic pods. Widespread high-grade metamorphism of the gneisses is suggested by the results of regional geochemical patterns from assays of surface materials in the area (A. Steenfelt, personal communication, 1994). Some of the incompatible elements show a profound difference between the eclogite-bearing gneisses north of Dove Bugt and gneisses to the south. The gneisses north of latitude $76^{\circ} \mathrm{N}$ have markedly lower values of $\mathrm{U}$ and $\mathrm{Th}$, a characteristic of many granulite facies terranes (Taylor \& McLennan, 1985; Steenfelt, 1987, 1990).

\section{Geochemistry and mineralogy}

The eclogites, garnet clinopyroxenites, websterites and garnet websterites all have basic $\left(245 \% \mathrm{SiO}_{2}\right)$ bulk compositions. Some representative bulk geochemical analyses for these lithologies are given in Table 3. Samples were analysed by X-ray fluorescence following standard GGU procedures (Kalsbeek, 1990). $\mathrm{FeO}$ and $\mathrm{Fe}_{2} \mathrm{O}_{3}$ were determined by titration. The samples show a limited range of compositions, and most of them are fairly $\mathrm{Mg}$ rich. Assuming that there has been no significant meta-
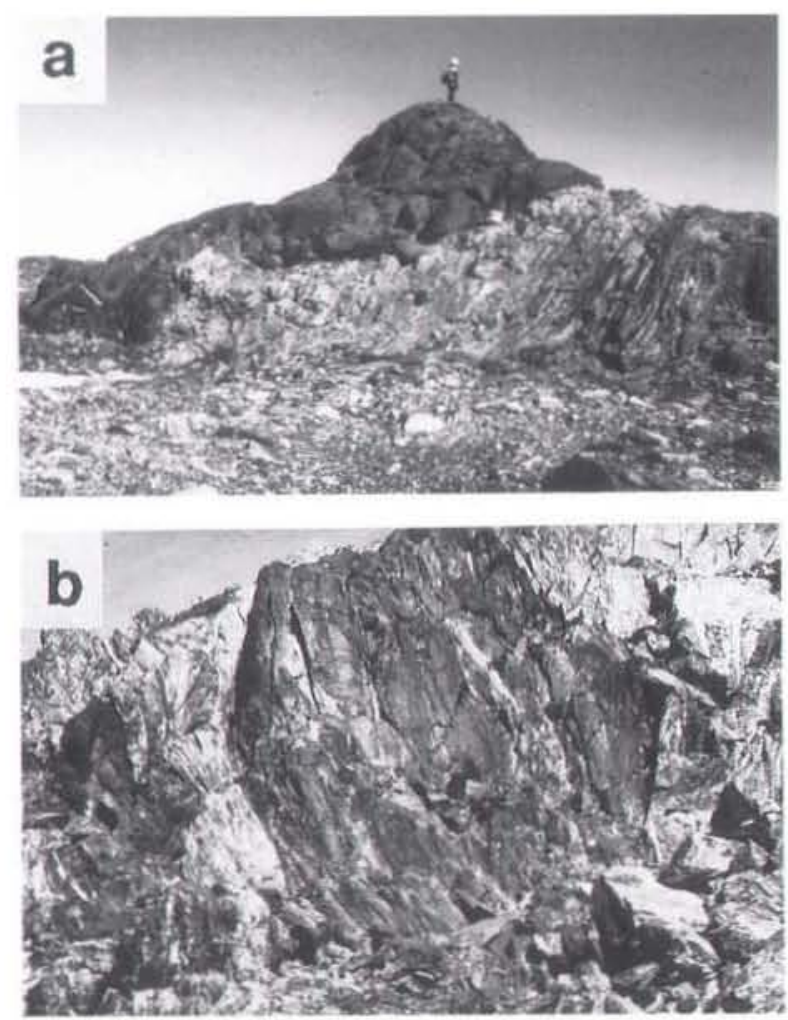

Fig. 4. (a) Massive garnet clinopyroxenite pod forming summit of hill: contact is oblique to the foliation of the underlying gneisses. J. D. Friderichsen for scale. (b) Eclogite pod 26 on Figure 1: inclined foliation within eclogite is concordant with that in the surrounding gneisses. Hammer at lower right for scale. 
somatism, only one sample, eclogite 363049 , is truly basaltic in composition. The other two eclogites and garnet clinopyroxenite 407504 are more $\mathrm{Mg}$-rich, with compositions similar to pyroxene-rich gabbros or norites. These samples contrast with other garnet clinopyroxenites, garnet websterites, and websterites (e.g. 363059, 363056 and 363007), where $\mathrm{Si}, \mathrm{Mg}$ and $\mathrm{Cr}$ suggest more primitive compositions. The protoliths of these samples were probably dominated by $\mathrm{Ca}-\mathrm{Mg}$ silicates; possibly they were pyroxene cumulates. Ultrabasic pods $\left(\mathrm{SiO}_{2}\right.$ $<45 \%)$ are rare in the study area; however, Friderichsen et al. (1991) found one dunite, and Wyllie (1957) recognised two olivine + spinel \pm orthopyroxene pods.

Most of the true eclogites are the bimineralic type, dominated by omphacite + garnet (Fig. 5a,b). Rutile, quartz, apatite and orthopyroxene occur mainly as inclusions in garnet and clinopyroxene. Titanite and opaque minerals, especially ilmenite, are also present. Zoisite was found in only one sample. Phengite is noticeably absent, but biotite sometimes appears to be part of the high-pressure assemblage (Fig. 5c). Textural evidence indicates that, in some cases, calcic amphibole is a primary phase, although it is more common as a retrograde mineral.

The only difference between the true eclogites and the garnet clinopyroxenites is in the composition of the clinopyroxene (Fig. 6), which reflects the bulk composition of the rock (Table 3). These two lithologies are impossible to distinguish in the field, since both can be colourful, fresh, and mineralogically and texturally similar in outcrop. Na-poor bulk compositions are most noticeable in the Danmarkshavn area, where bright green, very pristine garnet clinopyroxenites are common. The garnet clinopyroxenites are considered to be part of the family of highpressure rocks found in North-East Greenland by virtue of their similar mode of occurrence and proximity to the omphacite-bearing rocks.

Garnet websterites and websterites are also found throughout the region. The garnet websterites are composed of garnet + diopside + orthopyroxene \pm phlogopite \pm calcite \pm dolomite \pm titanite \pm ilmenite $\pm \mathrm{Fe}$-oxides. Embayed grain boundaries between the carbonate phases and the garnet and pyroxenes indicate pronounced grain boundary mobility at fairly high temperatures, and attest to the high-grade nature of the carbonates. Quartz, rutile and apatite are commonly found as inclusions in the three main phases. Plagioclase and amphibole are ubiquitous retrograde phases. The garnet websterites are petrologically similar to the 'orthopyroxene eclogites' in the Western Gneiss Region of Norway (Carswell et al., 1985;

Table 3. Whole rock analyses for representative eclogite facies rocks

\begin{tabular}{|c|c|c|c|c|c|c|c|c|}
\hline $\begin{array}{l}\text { Sample } \\
\text { GGU No }\end{array}$ & $\begin{array}{l}\text { ky-eclo } \\
407559\end{array}$ & $\begin{array}{l}\text { eclogite } \\
363049\end{array}$ & $\begin{array}{l}\text { eclogite } \\
363028\end{array}$ & $\begin{array}{l}\text { eclogite } \\
363054\end{array}$ & $\begin{array}{c}\text { gt-cpx } \\
407504\end{array}$ & $\begin{array}{c}\text { gt-cpx } \\
363059\end{array}$ & $\begin{array}{l}\text { gt-web } \\
363056\end{array}$ & $\begin{array}{c}\text { web } \\
363007\end{array}$ \\
\hline $\mathrm{SiO}_{2}$ & 50.05 & 50.86 & 52.90 & 49.54 & 48.43 & 51.90 & 48.70 & 52.84 \\
\hline $\mathrm{TiO}_{2}$ & 0.06 & 1.46 & 0.74 & 0.28 & 0.08 & 0.20 & 0.33 & 0.34 \\
\hline $\mathrm{Al}_{2} \mathrm{O}_{3}$ & 23.85 & 13.20 & 13.50 & 13.69 & 12.27 & 6.28 & 6.40 & 3.75 \\
\hline $\mathrm{Fe}_{2} \mathrm{O}_{3}$ & 1.75 & 4.15 & 2.56 & 4.13 & 3.50 & 1.82 & 7.28 & 1.55 \\
\hline $\mathrm{FeO}$ & 3.34 & 9.55 & 6.91 & 4.91 & 3.75 & 5.17 & 8.42 & 13.07 \\
\hline $\mathrm{MnO}$ & 0.07 & 0.21 & 0.16 & 0.23 & 0.14 & 0.15 & 0.25 & 0.34 \\
\hline $\mathrm{MgO}$ & 6.33 & 6.54 & 9.51 & 10.89 & 17.23 & 13.50 & 19.03 & 19.42 \\
\hline $\mathrm{CaO}$ & 9.87 & 9.71 & 10.24 & 11.74 & 13.51 & 19.07 & 8.92 & 6.37 \\
\hline $\mathrm{Na}_{2} \mathrm{O}$ & 3.17 & 2.73 & 1.92 & 3.23 & 0.61 & 0.89 & 0.25 & 0.58 \\
\hline $\mathrm{K}_{2} \mathrm{O}$ & 0.57 & 0.65 & 0.64 & 0.32 & 0.06 & 0.06 & 0.14 & 0.99 \\
\hline $\mathrm{P}_{2} \mathrm{O}_{5}$ & 0.01 & 0.12 & 0.08 & 0.03 & 0.00 & 0.01 & 0.04 & 0.02 \\
\hline Volatiles & 0.73 & 0.97 & 0.72 & 0.65 & 0.54 & 1.20 & 0.62 & 1.15 \\
\hline Total & 99.80 & 100.15 & 99.88 & 99.64 & 100.12 & 100.25 & 100.38 & 100.42 \\
\hline $\mathrm{Mg} \mathrm{No} *$ & 0.732 & 0.505 & 0.678 & 0.741 & 0.852 & 0.801 & 0.744 & 0.715 \\
\hline V & 6 & 242 & 169 & 114 & 68 & 147 & 156 & 31 \\
\hline $\mathrm{Cr}$ & 53 & 88 & 437 & 381 & 2118 & 1349 & 1011 & 1602 \\
\hline $\mathrm{Ni}$ & 109 & 73 & 157 & 119 & 318 & 109 & 338 & 979 \\
\hline $\mathrm{Cu}$ & 47 & 91 & 76 & 6 & 11 & 11 & 614 & 5 \\
\hline $\mathrm{Zn}$ & 50 & 135 & 80 & 167 & 72 & 72 & 145 & 251 \\
\hline $\mathrm{Rb}$ & 30 & 51 & 39 & 23 & 34 & 33 & 34 & 85 \\
\hline $\mathrm{Sr}$ & 1379 & 134 & 118 & 65 & 119 & 83 & 60 & 46 \\
\hline
\end{tabular}

${ }^{*} \mathrm{Mg} \mathrm{No}=\mathrm{Mg} /(\mathrm{Mg}+\mathrm{LFe})$ (molecular proportion). 

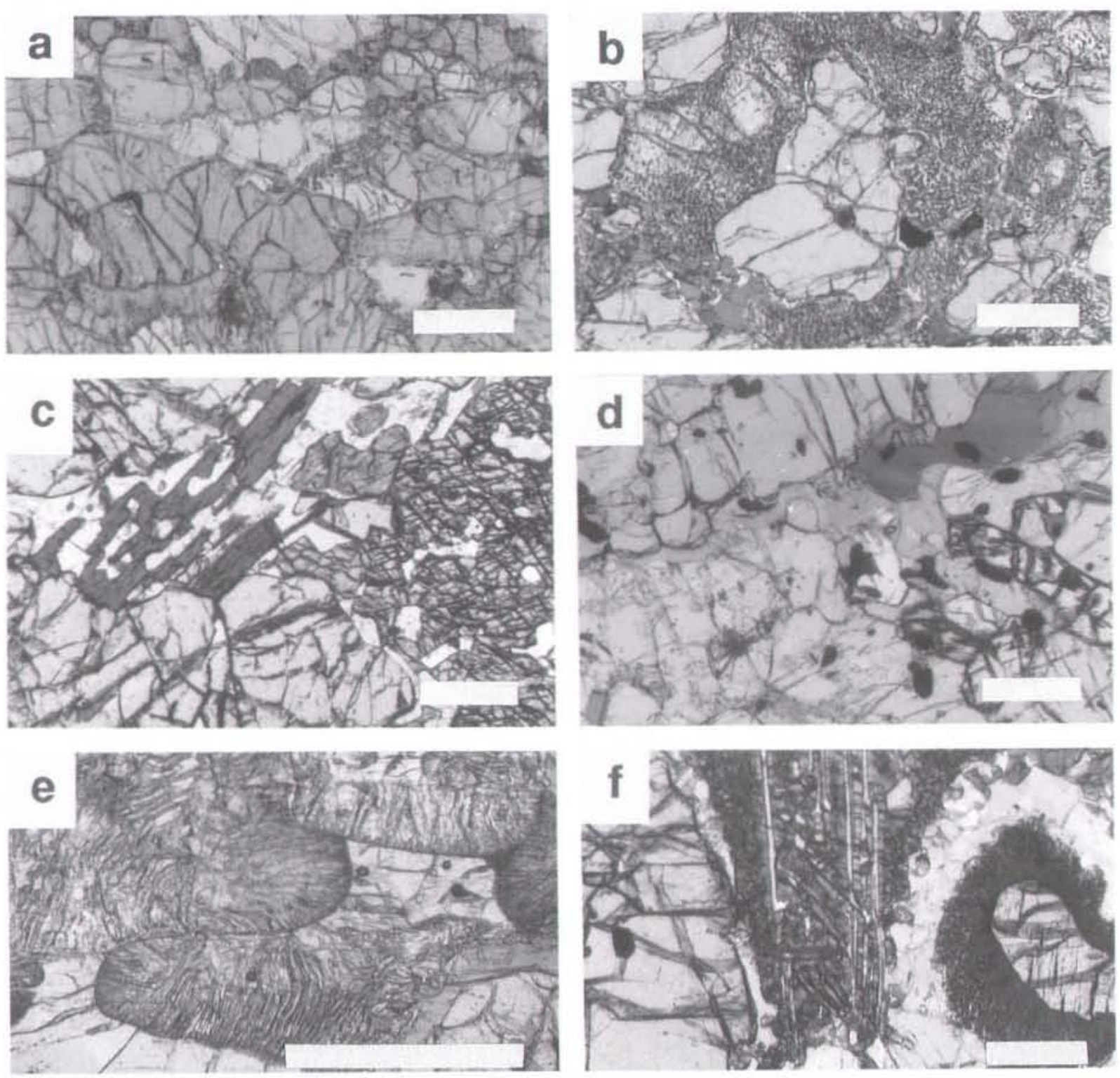

Fig. 5. Plane light photomicrographs of mineral assemblages and textures in the eclogite facies rocks. (a) Eclogite 363015 has a foliation defined by elongate grains of garnet (higher relief phase) and omphacite. Note incipient diopside + plagioclase symplectites along omphacite grain boundaries. (b) Garnet surrounded by sieved omphacite crystals in massive eclogite 363029. (c) Garnet + omphacite (right) + sieved biotite (dark phase) in eclogite 363149; retrograde plagioclase (light phase) forms along grain boundaries and in sieve holes. (d) Garnet websterite 363020: garnet, the high relief phase at the top of the photo, is separated from the diopside groundmass by a narrow rim of amphibole and biotite (dark phase) in upper right. The prominent high relief grains in the lower right are orthopyroxene, and the opaque mineral is ilmenite. (e) Lobate diopside-plagioclase symplectites replacing omphacite in eclogite 363054. (f) Garnet (left) + sieved diopside (center) + kyanite (right) in sample 407566. The dark, fuzzy, inner corona around kyanite is a symplectitic intergrowth of plagioclase + sapphirine + corundum; the outer corona is plagiociase. Scale bar is $0.5 \mathrm{~mm}$ in each photograph.

Smith, 1988). Websterites have quite Mg-rich bulk compositions and consist of enstatite + diopside $>$ phlogopite \pm anthophyllite \pm tremolite \pm serpentinite \pm quartz \pm plagioclase. The websterites are often very coarse- grained. A few of the pyroxenites contain over $90 \%$ orthopyroxene (e.g. Wyllie's 'bronzitite').

Eclogite facies assemblages have also been recognised in discrete bodies of acid-intermediate bulk composition. 
Fig. 6. Clinopyroxene mineral chemistry for eclogites and garnet clinopyroxenites from the Skærfjorden and the

Danmarkshavn areas.

Nomenclature for sodic pyroxenes follows Morimoto et al. (1988); Q is the quadrilateral pyroxene component, Jd is jadeite, and Ae is aegirine. The most sodic pyroxene is plotted for each sample, and the last three digits of the corresponding GGU sample number are also shown. An i indicates that omphacite was found as inclusions in garnet. Symbols as in Figure 1.

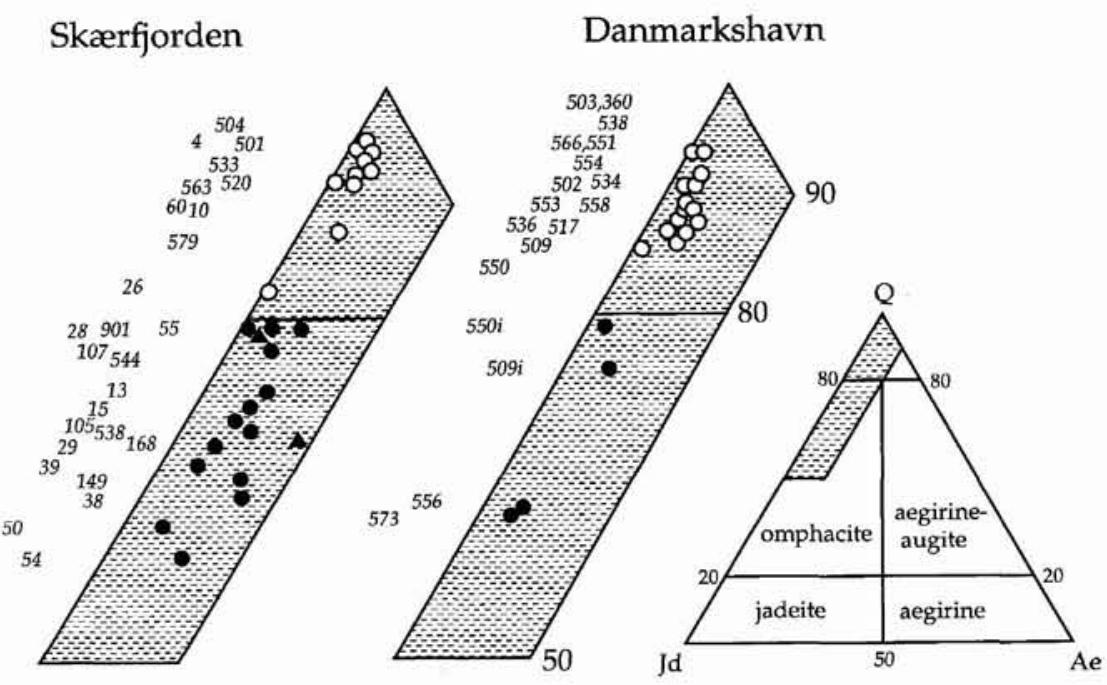

Two pods labeled 'felsic eclogite' in Figure 1 consist of a fine-grained, equilibrium mosaic of garnet + omphacite + phlogopite + oligoclase + K-feldspar + quartz. Kyaniteeclogite layers up to one metre thick have been found interbanded and folded together with bimineralic eclogites at two localities north-east of the Danmarkshavn weather station (Fig. 2). These two tabular kyaniteeclogite outcrops are quite large $(\sim 20 \times 100 \mathrm{~m}$ and $\sim 50 \times 300 \mathrm{~m}$ ) in comparison with typical eclogitic pods in the region. The kyanite-eclogite layers tend to have

Table 4. Clinopyroxene composition

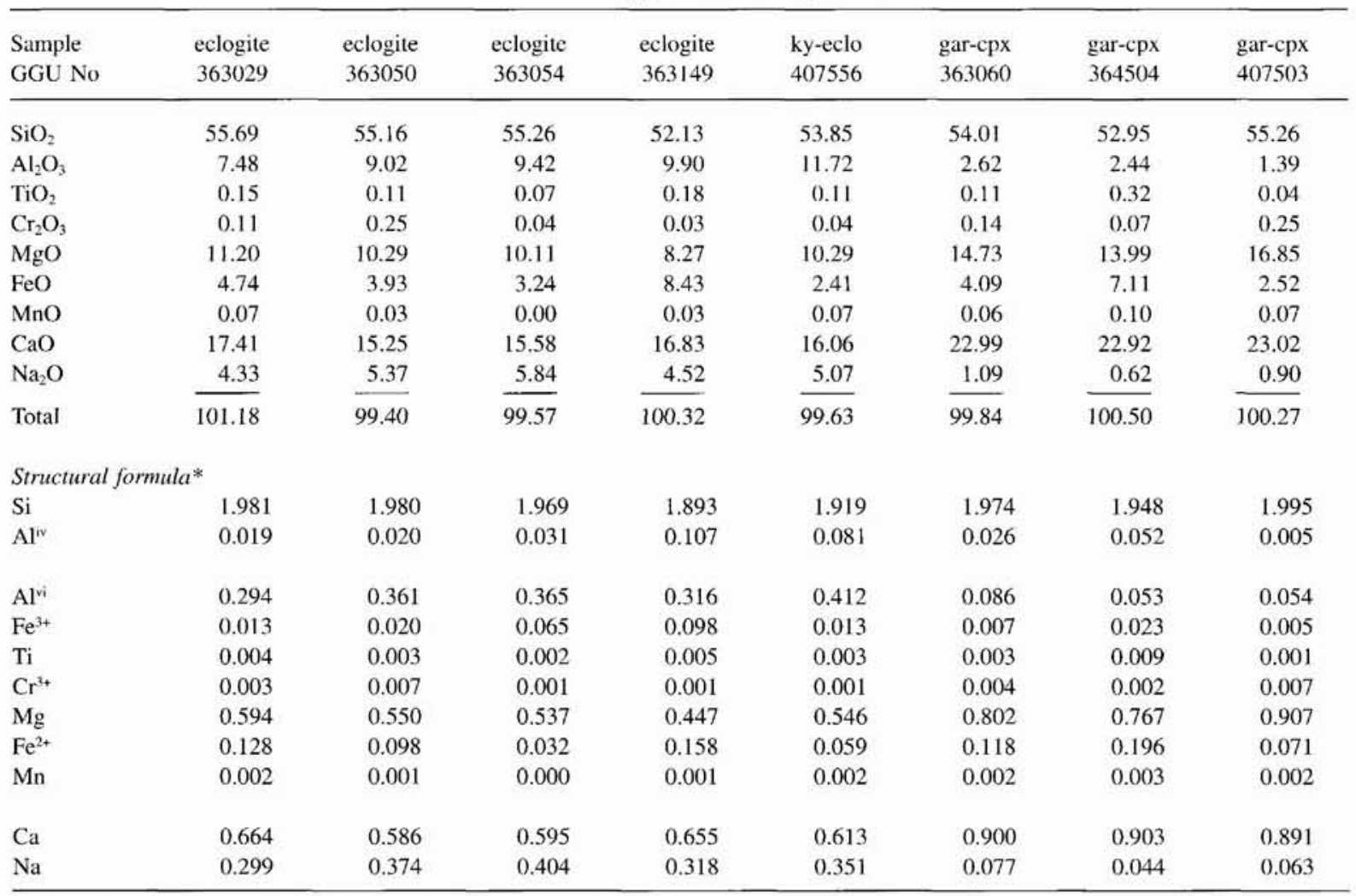

*cations $/ 6$ oxygen atoms, ferrous:ferric ratio adjusted to make 4 cations per formula unit. 
Table 5. Garnet composition

\begin{tabular}{|c|c|c|c|c|c|c|c|c|}
\hline $\begin{array}{l}\text { Sample } \\
\text { GGU No }\end{array}$ & $\begin{array}{l}\text { eclogite } \\
363029\end{array}$ & $\begin{array}{l}\text { eclogite } \\
363050\end{array}$ & $\begin{array}{l}\text { eclogite } \\
363054\end{array}$ & $\begin{array}{l}\text { eclogite } \\
363149\end{array}$ & $\begin{array}{l}\text { ky-eclo } \\
407556\end{array}$ & $\begin{array}{l}\text { gar-cpx } \\
363060\end{array}$ & $\begin{array}{l}\text { gar-cpx } \\
364504\end{array}$ & $\begin{array}{l}\text { gar-cpx } \\
407503\end{array}$ \\
\hline $\mathrm{SiO}_{2}$ & 40.51 & 40.39 & 39.75 & 39.28 & 41.45 & 39.72 & 39.55 & 41.20 \\
\hline $\mathrm{Al}_{2} \mathrm{O}_{3}$ & 22.81 & 22.96 & 22.68 & 21.72 & 23.42 & 21.92 & 22.29 & 23.44 \\
\hline $\mathrm{TiO}_{2}$ & na & na & na & na & 0.06 & na & 0.21 & 0.02 \\
\hline $\mathrm{Cr}_{2} \mathrm{O}_{3}$ & na & na & na & na & 0.02 & na & 0.00 & 0.46 \\
\hline $\mathrm{MgO}$ & 9.78 & 10.62 & 9.48 & 4.58 & 14.19 & 8.79 & 6.65 & 18.26 \\
\hline $\mathrm{FeO}$ & 21.00 & 22.15 & 20.69 & 21.87 & 10.89 & 18.68 & 22.24 & 11.57 \\
\hline $\mathrm{MnO}$ & 0.42 & 0.63 & 0.76 & 0.49 & 0.18 & 0.75 & 0.44 & 0.26 \\
\hline $\mathrm{CaO}$ & 7.85 & 4.73 & 7.74 & 13.61 & 10.45 & 10.07 & 10.60 & 4.68 \\
\hline Total & 102.37 & 101.48 & 101.10 & 101.55 & 100.66 & 99.94 & 101.98 & 99.89 \\
\hline \multicolumn{9}{|c|}{ Structural formula* } \\
\hline $\mathrm{Si}$ & 2.996 & 3.004 & 2.982 & 3.000 & 2.996 & 3.010 & 2.983 & 2.968 \\
\hline $\mathrm{Al}$ & 1.989 & 2.013 & 2.006 & 1.956 & 1.996 & 1.958 & 1.982 & 1.991 \\
\hline $\mathrm{Ti}$ & 0 & 0 & 0 & 0 & 0.003 & 0 & 0.012 & 0.001 \\
\hline $\mathrm{Cr}^{3+}$ & 0 & 0 & 0 & 0 & 0.001 & 0 & 0.000 & 0.026 \\
\hline $\mathrm{Mg}$ & 1.078 & 1.177 & 1.060 & 0.521 & 1.529 & 0.993 & 0.747 & 1.960 \\
\hline $\mathrm{Fe}^{2+}$ & 1.299 & 1.378 & 1.298 & 1.397 & 0.658 & 1.184 & 1.403 & 0.697 \\
\hline Mn & 0.026 & 0.040 & 0.048 & 0.032 & 0.011 & 0.048 & 0.028 & 0.016 \\
\hline $\mathrm{Ca}$ & 0.622 & 0.377 & 0.622 & 1.114 & 0.809 & 0.818 & 0.857 & 0.361 \\
\hline \multicolumn{9}{|c|}{ End member composition } \\
\hline Pyr & 0.356 & 0.396 & 0.350 & 0.170 & 0.508 & 0.326 & 0.246 & 0.646 \\
\hline Alm & 0.429 & 0.464 & 0.429 & 0.456 & 0.219 & 0.389 & 0.462 & 0.230 \\
\hline Spe & 0.009 & 0.013 & 0.016 & 0.010 & 0.004 & 0.016 & 0.009 & 0.005 \\
\hline Grs & 0.206 & 0.127 & 0.205 & 0.364 & 0.269 & 0.269 & 0.282 & 0.119 \\
\hline
\end{tabular}

*cations/12 oxygen atoms; na $=$ not analyzed.

anorthositic bulk compositions (e.g. sample 407559, Table 3).

Almost all of the high-pressure assemblages have been overprinted to some extent by retrograde reaction products. Decompression is often marked by the replacement of omphacite by diopside + plagioclase symplectites. The symplectites initiate along omphacite grain boundaries
(Fig. 5a), and commonly develop distinct lobate forms (Fig. 5e). The decrease in lamellar spacing, e.g. at the edge of the lobes in Figure 5e, is thought to represent a drop in temperature during the symplectite-forming discontinuous precipitation reaction (Boland \& Van Roermund, 1983; Joanny et al., 1991). In addition to the symplectites, clinopyroxene also exhibits simple sieve

\section{Skærfjorden Danmarkshavn}

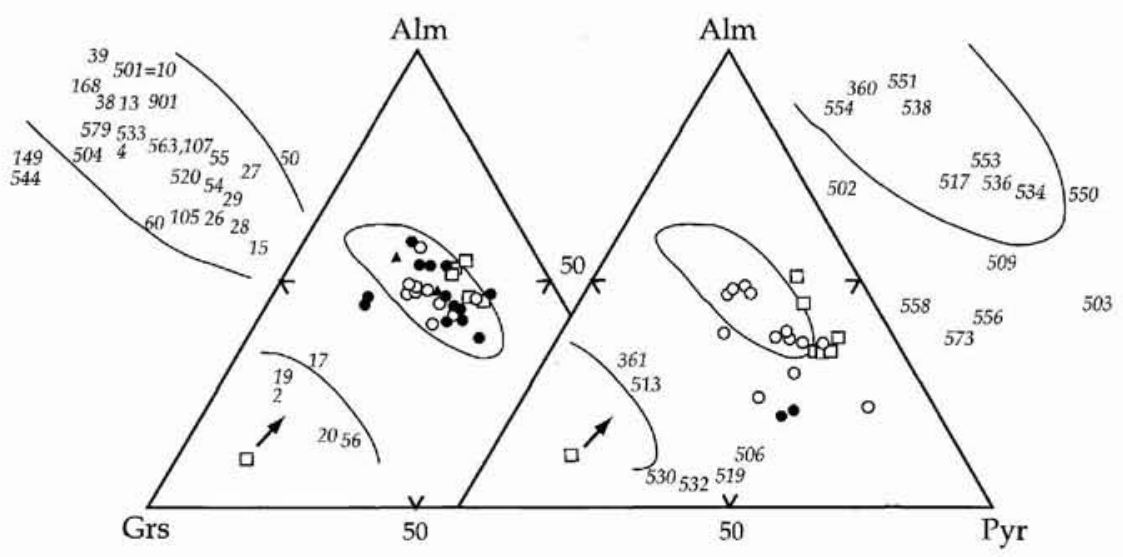

Fig. 7. Garnet mineral chemistry for eclogites, garnet clinopyroxenites, and garnet websterites plotted in almandine-pyrope-grossular (Alm-Pyr-Grs) ternary space. The garnet analysis with the lowest $\mathrm{Fe}: \mathrm{Mg}$ ratio is plotted for each sample. Symbols same as in Figure 1. The last three digits of the GGU sample number are also shown. Circled area is the field for eclogites typically found in gneiss terranes (Mottana, 1986). 
microstructures with plagioclase filling the holes (Fig. $5 \mathrm{~b}, \mathrm{c}, \mathrm{f})$. Plagioclase and green amphibole are the most common retrograde minerals. Both minerals preferentially grow at garnet-clinopyroxene grain boundaries (Fig. 5c, d,e). Plagioclase commonly forms complete coronas around garnet. The kyanite-eclogites are overprinted by sapphirine + plagioclase \pm corundum \pm spinel symplectites (Fig. 5f).

\section{Mineral chemistry}

Mineral chemistry data has been collected in a reconnaissance fashion from 62 samples of eclogitic rocks to date. The first goal of the microprobe analyses was to identify omphacite in order to separate the true eclogites from the garnet clinopyroxenites. A second goal was to characterise the mineral chemistry of the important phases in these high-pressure rocks. A summary of the mineral chemistry is presented below.

Clinopyroxene. Figure 6 shows the chemistry of the $\mathrm{Na}$ and $\mathrm{Na}-\mathrm{Ca}$ pyroxenes for eclogites and garnet clinopyroxenites; representative analyses are given in Table 4 . All pyroxene nomenclature follows Morimoto et al. (1988), including calculation of structural formulas and end members. $\mathrm{Fe}^{3+}$ has been estimated in the structural formula because $\mathrm{Fe}^{3+}$ is a common species in Na-pyroxenes (Mottana, 1986; Morimoto et al., 1988; Rossi, 1988). The bulk rock geochemistry also reveals significant amounts of $\mathrm{Fe}_{2} \mathrm{O}_{3}$ (Table 3), which is more likely to be found in clinopyroxene than garnet. The Skærfjorden (Fig. 1) and Danmarkshavn (Fig. 2) clinopyroxene populations have been split for clarity, but the reader should note that these regions are vastly different in size.

Omphacite has been found in approximately half of the garnet-clinopyroxene rocks from the Skærfjorden area. It is almost always colourless in thin section. The jadeite (Jd) component in the omphacite ranges from $20-36 \%$, the aegirine (Ae) component is $<10 \%$, and octahedrally coordinated aluminum ( $\mathrm{Al}^{\mathrm{vi}}$ ) varies between 0.18 to 0.37 . Omphacite, with $\mathrm{Jd}$ contents up to $36 \%$ and $\mathrm{Al}^{\mathrm{vi}}$ up to 0.41 , has also been found in the kyanite eclogites near Danmarkshavn. Clinopyroxene in the garnet clinopyroxenites is diopside, with $<5 \% \mathrm{Ae}, 4-18 \% \mathrm{Jd}$ and $\mathrm{Al}^{\mathrm{vi}}<0.25$. The diopside is often pale green in thin section, but can also be colourless. Clinopyroxene in the garnet websterites and websterites is diopside, with $1-14 \% \mathrm{Jd}$ and generally lower $\mathrm{Al}^{\mathrm{vi}}$ contents.

Orthopyroxene. Orthopyroxene is an important mineral in the garnet websterites and websterites. Orthopyroxene grains are colourless in thin section. They have the composition of enstatite, and vary between $\mathrm{En}_{83} \mathrm{Fs}_{17} \mathrm{Wo}_{0}$ and $\mathrm{En}_{63} \mathrm{Fs}_{33} \mathrm{Wo}_{2}$. The $\mathrm{Al}_{2} \mathrm{O}_{3}<2.5$ weight percent is relatively high, generally a little higher than orthopyroxenes surveyed by Carswell et al. (1985) in similar rocks from the Western Gneiss Region of Norway. The cores of the orthopyroxenes are generally lower in $\mathrm{Al}$ than the rims.

Garnet. Figure 7 is a plot of garnet compositions for eclogite, garnet clinopyroxenite and garnet websterite samples from Skærfjorden and Danmarkshavn. Some representative garnet analyses are given in Table 5. All but two of the Skærfjorden samples plot in the area typical of 'type B' eclogites found in gneiss terranes, as delineated by Mottana (1986). Garnets in the eclogites and the garnet clinopyroxenites have similar compositions. The scatter in the Danmarkshavn data partly reflects the overall more $\mathrm{Mg}$-rich bulk composition of the rocks. Garnets from garnet websterites in both areas are consistently lower in grossular component than garnets within eclogites and garnet clinopyroxenites.

Garnet grains exhibit homogeneous cores, and zoning is confined to an increase in the average $\mathrm{Fe}: \mathrm{Mg}$ ratio from cores to rims within $<50 \mu \mathrm{m}$ of the grain boundary. This type of zoning is thought to represent diffusional reequilibration between garnet and clinopyroxene on the exhumation path (Ghent, 1988). No prograde zoning or inclusions of protolith minerals have been observed in the garnets to date. Garnets commonly contain inclusions of other eclogite facies phases such as rutile, quartz and omphacite.

Biotite. Yellowish brown to reddish brown biotite is present in many of the eclogites and related high pressure rocks, and is sometimes in textural equilibrium with the eclogite facies assemblage (Fig. 5c). Biotite in the bimineralic eclogites has the composition $\mathrm{Fe} /(\mathrm{Fe}+\mathrm{Mg})=0.15$ to $0.50, \mathrm{Ti}=0.04$ to 0.27 per 3 octahedral sites, and $\mathrm{Al}^{\mathrm{v}} / 11$ anhydrous oxygen atoms $=0.03$ to 0.28 . The trioctahedral mica in the garnet clinopyroxenites, garnet websterites and websterites is phlogopite with $\mathrm{Fe} / \mathrm{Fe}+$ $\mathrm{Mg})=0.10$ to $0.32,0.19$ to 0.29 , and 0.10 to 0.18 , respectively; $\mathrm{Ti} \leq 0.21$ per 3 octahedral sites, and $\mathrm{Al}^{\mathrm{vi}} / 11$ anhydrous oxygen atoms $=0.06$ to 0.32 .

Amphibole. Green calcic amphibole is present in most of the eclogitic rocks. On the basis of textural relations, some of the amphibole could be interpreted as part of the high-pressure assemblage; however, most is clearly retrograde. Approximately 100 amphiboles were analysed; the results are summarised for structural formulas based on cations $/ 23$ anhydrous oxygen atoms where the ferrous: ferric ratio was calculated such that $\mathrm{Fe}+\mathrm{Mg}+\mathrm{Mn}+\mathrm{Ti}+$ $\mathrm{Al}+\mathrm{Si}=13$ per standard formula unit. Amphibole nomenclature follows Leake (1978).

Pargasite, pargasitic hornblende, tschermakitic horn- 


\section{Skærfjorden}

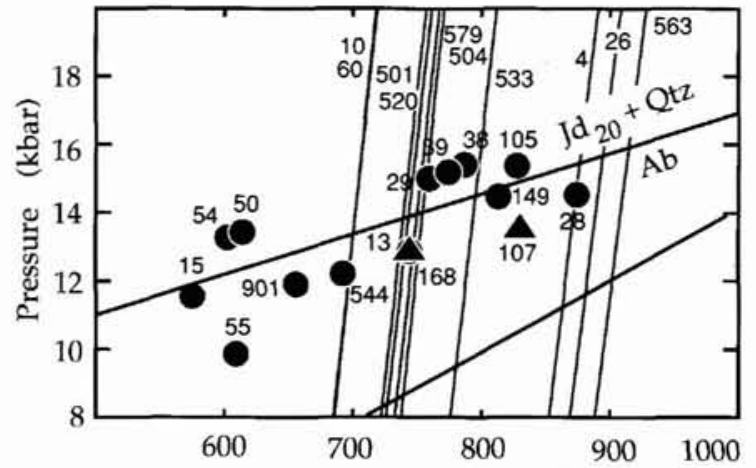

Danmarkshavn

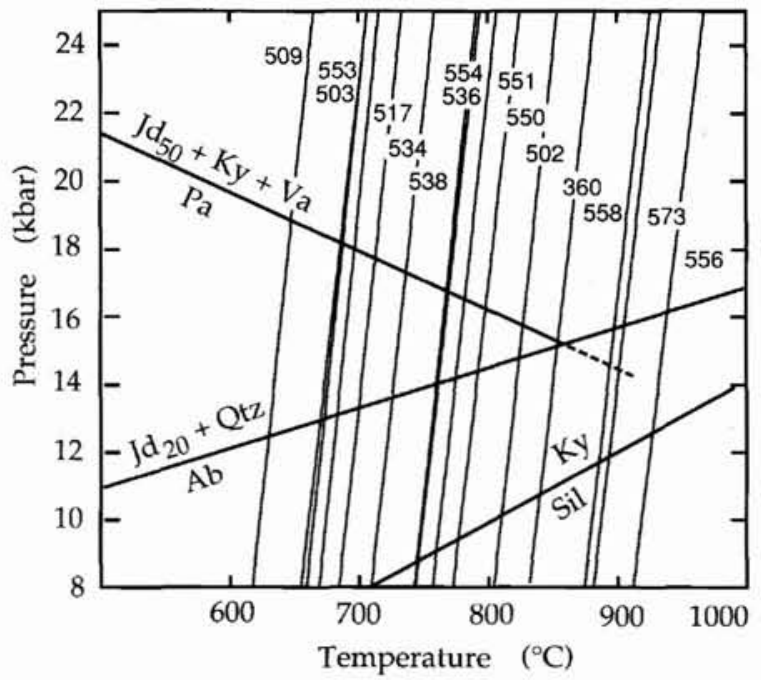

Fig. 8. Preliminary thermobarometry for eclogites and garnet clinopyroxenites from the Skærfjorden and Danmarkshavn areas. Steep lines show $\mathrm{K}_{\mathrm{D}}$ equilibria calculated from the Ellis \& Green (1979) thermometer. Symbols for Skærfjorden are eclogites where minimum pressure has also been estimated. The last three digits of the corresponding GGU sample numbers are shown. Albite $=$ jadeite $20+$ quartz $($ Holland, 1980), paragonite $=$ jadeite $_{50}+$ kyanite + vapor (Newton, 1986), and the kyanite to sillimanite transition (Holdaway, 1971) are shown for reference. Modified from Gilotti (1993).

blende, magnesio-hornblende and magnesio-hastingsitic hornblende are the most common amphiboles in the eclogites sensu stricto. These amphiboles are $\mathrm{Mg}$-rich with $\mathrm{Fe} /(\mathrm{Fe}+\mathrm{Mg})=0.01$ to $0.50, \mathrm{Ti}<0.20,(\mathrm{Na}+\mathrm{K})_{\mathrm{A}}=0.12$ to 0.83 , and $\mathrm{Si} / 23$ oxygens $=5.72$ to 7.40 . Amphiboles in the garnet clinopyroxenites are pargasitic hornblendes, tschermakitic hornblendes and magnesio-hornblendes with $\mathrm{Fe} /(\mathrm{Fe}+\mathrm{Mg})<0.35, \mathrm{Ti}=0.03$ to $0.29,(\mathrm{Na}+\mathrm{K})_{\mathrm{A}}=$ 0.29 to 0.73 , and $\mathrm{Si} / 23$ oxygens $=5.92-6.77$. Garnet websterites contain tschermakitic and magnesio-hornblendes with $\mathrm{Fe} /(\mathrm{Fe}+\mathrm{Mg})<0.25$. Anthophyllite, an orthoamphibole, is present in the websterites along with tremolite; both of these amphiboles indicate very $\mathrm{Mg}$-rich bulk compositions.

Plagioclase. Oligoclase $\left(\mathrm{X}_{\mathrm{an}}=0.11\right.$ to $\left.0.25, \mathrm{X}_{\mathrm{or}}<0.03\right)$ is in equilibrium with the high-pressure assemblage in the two eclogites of acid-intermediate composition. Retrograde plagioclase $\left(\mathrm{X}_{\mathrm{or}} \leq 0.03\right)$ is present in all but two of the eclogite and garnet clinopyroxenite samples. The plagioclase is generally more sodic in the true eclogites, $\left(\mathrm{X}_{\text {an }}\right.$ $=0.08$ to 0.41$)$, than in the garnet clinopyroxenites $\left(\mathrm{X}_{\mathrm{an}}=\right.$ 0.21 to 0.96 ). Retrograde plagioclase in the garnet websterites has compositions with $\mathrm{X}_{\mathrm{or}}<0.02$ and $\mathrm{X}_{\mathrm{an}}=0.21$ to 0.40 .

\section{Thermobarometric estimates}

Temperature estimates for the eclogite facies metamorphism are given for eclogites and garnet clinopyroxenites in Figure 8. The Skærfjorden and Danmarkshavn sample populations have been divided for clarity. Temperatures were calculated using the $\mathrm{Fe}-\mathrm{Mg}$ exchange reaction between garnet and clinopyroxene (Ellis \& Green, 1979) by pairing the most jadeite-rich clinopyroxene with the most pyrope-rich garnet from each sample. Examples of such mineral pairs can be constructed from Tables 4 and 5. This method follows the rationale of Griffin et al. (1985) to obtain the maximum temperature for the eclogite facies metamorphism. Following Griffin et al. (1985), $\mathrm{Fe}^{3+}$ has been calculated for the garnet and clinopyroxene compositions, causing the temperatures to be up to $50-150^{\circ} \mathrm{C}$ lower than if all $\mathrm{Fe}$ is taken as divalent. The lowest temperature eclogites (Fig. 8) from the Skærfjorden area generally have omphacite with high ferric iron contents. If only divalent $\mathrm{Fe}$ was considered, the range in temperatures in Figure 8 would be smaller, and the lowest temperatures would be approximately $700^{\circ} \mathrm{C}$.

Temperature estimates for the North-East Greenland eclogites and related rocks fall in the range of $600-900^{\circ} \mathrm{C}$ (Fig. 8), the medium-temperature eclogite field of Carswell (1990). Medium-temperature eclogites are typically formed in overthickened crust during continental collision. No systematic variation in temperature can be discerned within the study area. Temperature estimates vary as much in the small area around Danmarkshavn as in the whole of Skærfjorden.

Pressures are notoriously difficult to establish in bimineralic eclogites (Newton, 1986; Schreyer, 1988). Following Griffin $e t$ al. (1985), minimum pressures between 9 and 14 kbars were estimated for the Skærfjorden eclogites using the albite $=$ jadeite + quartz reaction (Holland, 
1980), and assuming the coexistence of omphacite, quartz and albite during the eclogite facies metamorphism. Pressures in excess of 15 kbars are likely for the kyanite + omphacite eclogites (Newton, 1986) from Danmarkshavn (samples 407558, 407573 and 407556). More detailed work is needed to obtain better pressure estimates for the North-East Greenland eclogites; studies in progress will focus on lower variance assemblages in the 'felsic' eclogites, kyanite-eclogites and garnet websterites.

\section{Chronology of events}

The age of the eclogite facies metamorphism is difficult to determine from field evidence alone, as not all of the field relations are consistent with either Early Proterozoic or Caledonian metamorphism (Friderichsen et al., 1991; Gilotti, 1993). The Precambrian versus Caledonian origin for the Greenland eclogites appears to be resolved by preliminary $\mathrm{Sm}-\mathrm{Nd}$ and $\mathrm{Rb}-\mathrm{Sr}$ mineral isochrons (Brueckner \& Gilotti, 1993; H. K. Brueckner, personal communication). Garnet-clinopyroxene-whole rock \pm orthopyroxene \pm amphibole \pm biotite $\mathrm{Sm}-\mathrm{Nd}$ mineral isochrons from two garnet websterites and one eclogite sensu stricto give Palaeozoic ages ranging from 435-370 Ma. Although Sm-Nd mineral isochron ages are essentially cooling ages, they generally approximate the time of eclogite facies metamorphism because of the relatively high closure temperatures for $\mathrm{Sm}-\mathrm{Nd}$ in eclogite facies minerals relative to other parent-daughter systems (for a review see Gebauer, 1990). A Caledonian age is tentatively accepted for the eclogite facies metamorphism, recognising that the Sm-Nd system may have equilibrated somewhat later than the eclogite-facies event if exhumation was slow and/or heating occurred. $\mathrm{Rb}-\mathrm{Sr}$ mineral isochron ages obtained from the same three samples are consistently younger at $\sim 360-290 \mathrm{Ma}$.

Host gneisses to the eclogites have been dated in only a few localities. Steiger et al. (1976) obtained an Archaean intrusive age of $\sim 3000 \pm 150$ Ma for a granodioritic gneiss at Danmarkshavn (Fig. 2) from standard U-Pb analysis of a zircon suite. This age has recently been confirmed by $\mathrm{U}-\mathrm{Pb}$ single zircon analysis using the SHRIMP (Nutman \& Kalsbeek, 1994). Archaean rocks are considered to be uncommon in the region, but their areal extent is not known at present. The majority of the gneisses in North-East Greenland are thought to have Early Proterozoic intrusive ages (Kalsbeek et al., 1993; Hull et al., 1994). U-Pb single crystal zircon analyses on two gneisses from the Dove Bugt region yielded Early Proterozoic (1974 $\pm 17 \mathrm{Ma}$ and $1764 \pm 20 \mathrm{Ma}$ ) 207/206 $\mathrm{Pb}$ weighted mean ages (Kalsbeek et al., 1993), while a similar sample collected east of the Germania Land de- formation zone is $1963 \pm 6$ Ma (Nutman \& Kalsbeek, 1994). Tucker et al. (1993) obtained similar results from a granitoid gneiss in south-eastern Dronning Louise Land, about $160 \mathrm{~km}$ south-west of Danmarkshavn, where U-Pb analysis of a zircon suite gave a crystallisation age of $1909_{-5}^{+6}$ Ma. Xenoliths of mafic and ultramafic rocks would have been incorporated into these batholiths between 1.8-3.0 Ga ago.

Early Proterozoic plutonism was closely followed by a deformation event that produced an intense tectonic fabric in the rocks (Hull et al., 1994). This gneissosity envelops many of the eclogitic pods (e.g. Figs 3, 4b), but is clearly cross-cut by metagranitoid sheets in numerous outcrops. One of these late intrusions gives a zircon $\mathrm{U}-\mathrm{Pb}$ upper intercept age of $1739 \pm 11 \mathrm{Ma}$ (Kalsbeek et al., 1993). Both the gneisses and the metagranitoid sheets are cut by pre-Caledonian metadolerite dykes. The simple fabrics in the metagranitoid sheets and metadolerite dykes are attributed to Caledonian deformation and metamorphism, while some of the eclogites and migmatitic orthogneisses are likely to have composite Precambrian and Caledonian fabrics. Caledonian metamorphism is indicated by $420-400 \mathrm{Ma} \mathrm{U}-\mathrm{Pb}$ lower intercepts on zircons from the gneisses and metagranitoids (Kalsbeek et al., 1993; Tucker et al., 1993), by Rb-Sr mineral isochrons (Steiger et al., 1976; Brueckner \& Gilotti, 1993; H. K. Brueckner, personal communication), and by ${ }^{40} \mathrm{Ar} /{ }^{39} \mathrm{Ar}$ mineral cooling ages obtained from a variety of samples in the study area (Dallmeyer et al., 1994).

\section{Discussion and conclusions}

The North-East Greenland eclogite province is a medium-temperature eclogite terrain of significant proportions. Agmatites preserved in low strain augen within the gneiss complex indicate that at least some of the eclogite protoliths were xenoliths picked up by batholiths that were later deformed and metamorphosed to form the Skærfjorden gneiss complex. The xenoliths may represent initial basic intrusive phases of the Early Proterozoic calc-alkaline batholiths, akin to the consanguineous intrusive history in the Sierra Nevada batholith (e.g. Stern et al., 1981). Alternatively, preexisting (Archaean?) layered basic intrusions could have been the source of these xenoliths. In either case, the xenoliths indicate that the protoliths of at least some of the eclogitic pods have been longtime residents of the crust, and have shared with their hosts a long history of gneiss formation and deformation.

The pervasive overprinting of eclogite facies assemblages by retrograde assemblages is a well documented phenomenon of many eclogite terrains. The result is that only a tiny volume of eclogite facies rocks are exhumed 
to the surface intact, usually as small pods and lenses. The poor preservation of eclogitic rocks in general has led to two different interpretations of medium-temperature eclogite terrains. The first (e.g. Coleman et al., 1965; Smith, 1988), is that the eclogites were formed at great depths and then tectonically emplaced into continental crust that never experienced eclogite facies conditions. The second interpretation (e.g. Griffin et al., 1985; Cuthbert \& Carswell, 1990; Droop et al., 1990) is that eclogites form in situ in their host gneisses, with subsequent retrogression destroying the high-pressure mineralogy in the host.

The current working hypothesis for the North-East Greenland eclogite province, based mostly on the xenolith protoliths of some eclogitic rocks, is that the entire gneiss complex was subjected to eclogite facies conditions. Although no unequivocal eclogite facies assemblages have been found in the gneisses to date, the 'felsic' eclogites are additional evidence that crustal rocks saw high-pressure metamorphic conditions. Future work on the quartzofeldspathic rocks, particularly in the low strain augen and the later metagranitoids, may reveal eclogite facies jadeite + quartz assemblages, such as the classic Alpine occurrences at Monte Mucrone (e.g. Oberhänsli $e t$ al., 1985) and the Dora Maira massif (e.g. Biino \& Compagnoni, 1992). Future studies should also focus on late basic intrusions into the gneisses, such as the crosscutting metadolerite dykes and the metagabbros in the eastern part of the study area (Hull et al., 1994), since mafic and ultramafic rocks have a better chance of surviving retrogression than quartzofeldspathic lithologies (Koons \& Thompson, 1985).

In addition to pervasive retrogression during exhumation, eclogite facies rocks may be a volumetrically minor constituent of gneiss terrains because of incomplete transformations during high-pressure metamorphism. For example in the Bergen Arcs of Norway, eclogites are spatially restricted to deformation zones and fluid infiltration fronts which cut across lithologic boundaries in the host granulites (Austrheim \& Griffin, 1985; Austrheim, 1990; Klaper, 1990). Mørk (1985) describes a similar incomplete transformation of gabbro to eclogite in western Norway. Localised deformation and fluid infiltration were necessary to transform granulites and gabbros to eclogites in these examples. The preservation of the granulites and gabbros indicates that the protoliths were metastable in the eclogite facies. These examples caution against expecting that large slabs of crust are ever completely transformed to eclogite. Given the complex history of Precambrian and Caledonian deformation and metamorphism in North-East Greenland, it is possible that pre-Caledonian enclaves of igneous and/or metamorphic assemblages could have escaped Caledonian metamorphism. Detailed field and petrologic studies will be required to address these issues.

Eclogite formation in North-East Greenland appears to be broadly synchronous with eclogite formation in the Scandinavian Caledonides. The Sm-Nd mineral ages for Greenland samples are Palaeozoic (H. K. Brueckner, personal communication), and essentially comparable to Sm-Nd mineral isochron ages of $447-400 \mathrm{Ma}$ (Griffin \& Brueckner, 1980, 1985; Mørk \& Mearns, 1986) and the U-Pb zircon ages of c. $400 \mathrm{Ma}$ (Gebauer et al., 1985; Sutter et al., 1991) for eclogitic rocks in the Western Gneiss Region of Norway. Palaeozoic medium-temperature eclogites are also found in Spitsbergen (Peucat $e t$ al., 1989), though their age is not well-constrained.

The discovery of such a large eclogite province in North-East Greenland, combined with known Palaeozoic eclogites in Newfoundland (Jamieson, 1990), and the possibility of Caledonian high-pressure rocks in Liverpool Land and Payers Land, indicate that eclogite formation is more important along the Laurentian margin of the Caledonian orogeny than previously recognised. Much more work is needed in order to understand the physical conditions and timing of eclogite formation in the Greenland Caledonides. These future studies will have an impact on correlations of eclogite-bearing gneisses throughout the circum-Atlantic region, and are crucial to understanding and modelling the tectonics of collision in the North Atlantic Caledonides.

Acknowledgements. This work was supported by GGU and the New York State Museum. Mineral chemistry data were obtained using the JEOL 733 Superprobe in WDS mode at the Department of Earth and Environmental Sciences, Rensselaer Polytechnic Institute, Troy, NY. Special thanks go to Chris Supkis for photographic work, and Dave Wark for help with the probe. I am indebted to my field partners, J. M. Hull, J. D. Friderichsen and A. K. Higgins, for their help with this project.

\section{References}

Austrheim, H. 1990: The granulite-eclogite facies transition: a comparison of experimental work and a natural occurrence in the Bergen Arcs, western Norway. Lithos 25, 163-169.

Austrheim, H. \& Griffin, W.L. 1985: Shear deformation and eclogite formation within granulite-facies anorthosites of the Bergen Arcs, western Norway. Chem. Geol. 50, 267-281.

Backlund, H. G. 1936: Zur genetischen Deutunt der Eklogite. Geol. Rundschau 27, 47-61.

Biino, G. \& Compagnoni, R. 1992: Very-high pressure metamorphism of the Brossasco coronite metagranite, southern Dora Maira Massif, Western Alps. Schweiz. min. petr. Mitt. 72, 347-363.

Boland, J. N. \& Van Roermund, H. L. M. 1983: Mechanisms of exsolution in omphacites from high temperature, type B, eclogites. Phys. Chem. Miner. 9, 30-37. 
Bronner, F. E. 1948: Contributions to the geology. In Boyd, L. A. (ed.) The coast of North-East Greenland. Am. geogr. Soc. Spec. Publ. 30, 211-224.

Brueckner, H. K. \& Gilotti, J. A. 1993: Preliminary age constraints on the timing of eclogite facies metamorphism, North-East Greenland Caledonides. Geol. Soc. Am. Abstracts with Programs 25, 340 only.

Carswell, D. A. 1990: Eclogites and the eclogite facies: definitions and classifications. In Carswell, D. A. (ed.) Eclogite facies rocks, 1-13, New York: Chapman and Hall.

Carswell, D. A., Krogh, E. J. \& Griffin, W. L. 1985: Norwegian orthopyroxene eclogites: calculated equilibration conditions and petrogenetic implications. In Gee, D. G. \& Sturt, B. A. (ed.) The Caledonian orogen - Scandinavia and related areas, 823-841, Chichester: John Wiley \& Sons.

Chadwick, B., Friend, C. R. L. \& Higgins, A. K. 1990: The crystalline rocks of western and southern Dove Bugt, NorthEast Greenland. Rapp. Gronlands geol. Unders. 148, 127132.

Cheeney, R. F. 1985: The plutonic igneous and high-grade metamorphic rocks of southern Liverpool Land, central East Greenland, part of a supposed Caledonian and Precambrian complex. Rapp. Gronlands geol. Unders. 123, 39 pp.

Coe, K. \& Cheeney, R. F. 1972: Preliminary results of mapping in Liverpool Land, East Greenland. Rapp. Gronlands geol. Unders. 48, 7-20.

Coleman, R. G., Lee, D. E., Beatty, L. B. \& Brannock, W. W. 1965: Eclogites and eclogites: their differences and similarities. Geol. Soc. Am. Bull. 76, 483-508.

Cuthbert, S. J. \& Carswell, D. A. 1990: Formation and exhumation of medium-temperature eclogites in the Scandinavian Caledonides. In Carswell, D. A. (ed.) Eclogite facies rocks, 180-203, New York: Chapman and Hall.

Dallmeyer, R. D., Strachan, R. A. \& Henriksen, N. 1994: ${ }^{40} \mathrm{Ar} /$ ${ }^{39} \mathrm{Ar}$ mineral age record in the North-East Greenland Caledonides. J. geol. Soc. Lond. 151, 615-628.

Droop, G. T. R., Lombardo, B. \& Pognante, U. 1990: Formation and distribution of eclogite facies rocks in the Alps. In Carswell, D. A. (ed.) Eclogite facies rocks, 225-259, New York: Chapman and Hall.

Ellis, D. J. \& Green, D. H. 1979: An experimental study of the effect of $\mathrm{Ca}$ upon garnet-clinopyroxene $\mathrm{Fe}-\mathrm{Mg}$ exchange equilibrium. Contr. Miner. Petr. 71, 13-22.

Friderichsen, J. D., Gilotti, J. A., Henriksen, N., Higgins, A. K., Hull, J. M., Jepsen, H. F. \& Kalsbeek, F. 1991: The crystalline rocks of Germania Land, Nordmarken and adjacent areas, North-East Greenland. Rapp. Grønlands geol. Unders. 152, 85-94.

Gebauer, D. 1990: Isotopic systems - geochronology of eclogites. In Carswell, D. A. (ed.) Eclogite facies rocks, 141-159, New York: Chapman and Hall.

Gebauer, D., Lappin, M., Grünenfelder, M. \& Wyttenbach, A. 1985: The age and origin of some Norwegian eclogites: A U-Pb zircon and REE-study. Chem. Geol. 52, 227-247.

Ghent, E. D. 1988: A review of chemical zoning in eclogite garnets. In Smith, D. C. (ed.) Eclogites and eclogite-facies rocks. Developments in Petrology 12, 207-231, Amsterdam: Elsevier.
Gilotti, J. A. 1993: Discovery of a medium-temperature eclogite province in the Caledonides of North-East Greenland. Geology 21, 523-526.

Griffin, W. L. \& Brueckner, H. K. 1980: Caledonian Sm-Nd ages and a crustal origin for Norwegian eclogites. Nature $\mathbf{2 8 5}$, 319-321.

Griffin, W. L. \& Brueckner, H. K. 1985: REE, Rb-Sr and Sm-Nd studies of Norwegian eclogites. Chem. Geol. 52, 249-271.

Griffin, W.L., Austrheim, H., Brastad, K., Bryhni, I., Krill, A. G., Krogh, E. J., Mørk, M. B. E., Qvale, H. \& Tørudbakken, B. 1985: High-pressure metamorphism in the Scandinavian Caledonides. In Gee, D. G. \& Sturt, B. A. (ed.) The Caledonian orogen - Scandinavia and related areas, 783 801, Chichester: John Wiley \& Sons.

Haller, J. 1956: Die Strukturelemente Ostgrönlands zwishen $74^{\circ}$ und $78^{\circ} \mathrm{N}$. Meddr Gronland 152(2) $27 \mathrm{pp}$.

Hill, E. J. \& Baldwin, S. L. 1993: Exhumation of high-pressure metamorphic rocks during crustal extension in the D'Entrecasteaux region, Papua New Guinea. J. metamorphic Geol. 11, 261-277.

Holdaway, M. J. 1971: Stability of andalusite and the aluminium-silicate phase diagram. Am. J. Sci. 271, 97-131.

Holland, T. J. B. 1980: The reaction albite $=$ jadeite + quartz determined experimentally in the range $600-1200^{\circ} \mathrm{C}$. $\mathrm{Am}$. Mineralogist 65, 129-134.

Holdsworth, R. E. \& Strachan, R. A. 1991: Interlinked system of ductile strike slip and thrusting formed by Caledonian sinistral transpression in northeastern Greenland. Geology 19, 510-513.

Hull, J. M. \& Gilotti, J. A. 1994: The Germania Land deformation zone and related structures, North-East Greenland. Rapp. Gronlands geol. Unders. 162 (this volume).

Hull, J. M., Friderichsen, J. D., Gilotti, J. A., Henriksen, N., Higgins, A. K., \& Kalsbeek, F. 1994: Gneiss complex of the Skærfjorden region, $76^{\circ}-78^{\circ} \mathrm{N}$, North-East Greenland. Rapp. Gronlands geol. Unders. 162(this volume).

Jamieson, R. A. 1990: Metamorphism of an Early Paleozoic continental margin, western Baie Verte Peninsula, Newfoundland. J. metamorphic Geol. 8, 269-288.

Joanny, V., Van Roermund, H. \& Lardeaux, J. M. 1991: The clinopyroxene/plagioclase symplectite in retrograde eclogites: a potential geothermobarometer. Geol. Rundschau $\mathbf{8 0}$, 303-320.

Johansson, L. 1986: Mega-lenses and Scandian deformation in the basement of the northern part of the Western Gneiss Region, Vestranden, central Norwegian Caledonides. Geol. Fören. Stockh. Förh. 108, 287-289.

Kalsbeek, F. 1990: Geochemistry in GGU. Rapp. Gronlands geol. Unders. 148, 43-45.

Kalsbeek, F. \& Taylor, P. N. 1989: Programme of geochronology and isotope geochemistry in the Ammassalik district, South-East Greenland: an outline and preliminary results. Rapp. Gronlands geol. Unders. 146, 13-16.

Kalsbeek, F., Nutman, A. P. \& Taylor, P. N. 1993: Palaeoproterozoic basement province in the Caledonian fold belt of North-East Greenland. Precambrian Res. 63, 163-178.

Klaper, E. M. 1990: Reaction-enhanced formation of eclogitefacies shear zones in granulite-facies anorthosites. In Knipe, 
R. J. \& Rutter, E. H. (ed.) Deformation mechanisms, rheology and tectonics. Spec. Pub. Geol. Soc. Lond. 54, 167-173.

Koons, P. O. \& Thompson, A. B. 1985: Non-mafic rocks in the greenschist, blueschist and eclogite facies. Chem. Geol. 50, 3-30.

Krank, E. H. 1935: On the crystalline complex of Liverpool Land. Meddr Gronland 95(7), 122 pp.

Larsen, H. C. 1981: A high-pressure granulite facies complex in north-west Payers Land, East Greenland fold belt. Bull. geol. Soc. Denmark 29, 161-174.

Leake, B. E. 1978: Nomenclature of amphiboles. Can. Mineral. 16, 501-520.

Messiga, B., Tribuzio, R. \& Vannucci, R. 1990: Mafic and ultramafic pods with eclogitic relics from the Proterozoic Nagssugtoqidian mobile belt of East Greenland. Lithos 25, 101-118.

Morimoto, N., Fabries, J., Ferguson, A. K., Ginzburg, I. V., Ross, M., Seifert, F. A. Zussman, J., Aoki, K. \& Gottardi, G. 1988: Nomenclature of pyroxenes. Am. Mineralogist 73, 1123-1133.

Mørk, M. B. E. 1985: A gabbro to eclogite transition on Flemsøy, Sunmøre, western Norway. Chem. Geol. 50, 283-310.

Mørk, M. B. E. \& Mearns, E. W. 1986: Sm-Nd isotopic systematics of a gabbro-eclogite transition. Lithos 19, 255-267.

Mottana, A. 1972: Eclogite occurrences in gneiss as indicators of a Caledonian high-pressure metamorphism in the Western Alps. Proc. 24th Int. Geol. Congress 2, 35-41.

Mottana, A. 1986: Crystal-chemical evaluation of garnet and omphacite microprobe analyses: its bearing on the classification of eclogites. Lithos 19, 171-186.

Newton, R. C. 1986: Metamorphic temperatures and pressures of Group B and C eclogites. Geol. Soc. Am. Memoir 164, 17-30.

Nutman, A. P. \& Friend, C. R. L. 1989: Reconnaissance $P, T$ studies of Proterozoic crustal evolution of the Ammassalik area, East Greenland. Rapp. Gronlands geol. Unders. 146, $48-53$.

Nutman, A. P \& Kalsbeek, F. 1994: Search for Archaean basement in the Caledonian fold belt of North-East Greenland. Rapp. Gronlands geol. Unders. 162 (this volume).

Oberhänsli, R., Hunziker, J. C., Martinotti, G. \& Stern, W. B. 1985: Geochemistry, geochronology and petrology of Monte Mucrone: an example of Eo-Alpine eclogitization of Permian granitoids in the Sesia-Lanzo zone, Western Alps, Italy. Chem. Geol. 52, 165-184.

Peucat, J. J., Ohta, Y., Gee, D. G. \& Bernard-Griffiths, J. 1989: $\mathrm{U}-\mathrm{Pb}, \mathrm{Sr}$ and $\mathrm{Nd}$ evidence for Grenvillian and latest tectonothermal activity in the Spitsbergen Caledonides, Arctic Ocean. Lithos 22, 275-285.

Rossi, G. 1988: A review of the crystal-chemistry of clinopyroxenes in eclogites and other high-pressure rocks. In Smith, D. C. (ed.) Eclogites and eclogite-facies rocks. Developments in Petrology 12, 237-270, Amsterdam: Elsevier.

Sahlstein, T. G. 1935: Petrographie der Eklogitsteinschlisse in den Gneisen des südwestlichen Liverpool-Landes in OstGrönland. Meddr Gronland 95(5), 43 pp.
Schreyer, W. 1988: Subduction of continental crust to mantle depths: petrological evidence. Episodes 11, 97-104.

Smith, D. C. 1988: A review of the peculiar mineralogy of the 'Norwegian Coesite-Eclogite Province' with crystal-chemical, petrological, geochemical, and geodynamical notes and an extensive bibliography. In Smith, D.C. (ed.) Eclogites and eclogite-facies rocks. Developments in Petrology 12, 1-206, Amsterdam: Elsevier.

Smith, D. C. \& Cheeney R.F. 1980: Oriented needles of quartz in clinopyroxene: evidence for exsolution of $\mathrm{SiO}_{2}$ from a non-stoichiometric supersilicic "clinopyroxene". 26th Int. Geol. Congress, Paris, France, (abstract) 1, 145 only.

Smith, D. C. \& Cheeney R. F. 1981: A new occurrence of garnet-ultrabasite in the Caledonides: a $\mathrm{Cr}$-rich chromitegarnet-lherzolite from Tvaerdalen, Liverpool Land, East Greenland. Terra Cognita 1, 74 only.

Sørensen, K. 1983: Growth and dynamics of the Nordre Strømfjord shear zone. J. geophys. Res. 88, 3419-3437.

Steenfelt, A. 1987: Geochemical mapping and prospecting in Greenland - a review of results and experience. J. geochem. Explor. 29, 183-205.

Steenfelt, A. 1990: Geochemical patterns related to major tectono-stratigraphic units in the Precambrian of northern Scandinavia and Greenland. J. geochem. Explor. 39, 35-48.

Steiger, R. H., Harnik-Šptrajanova, G., Zimmermann, E. \& Henriksen, N. 1976: Isotopic age and metamorphic history of the banded gneiss at Danmarkshavn, East Greenland. Contr. Miner. Petr. 57, 1-24.

Stern, T. W., Bateman, P. C., Morgan, B. A., Newell, M. F. \& Peck, D.L. 1981: Isotopic U-Pb ages of zircon from the granitoids of the central Sierra Nevada, California. U.S. Geol. Survey Prof. Paper 1185, 17 pp.

Strachan, R. A., Jepsen, H. F. \& Kalsbeek, F. 1991: Regional Caledonian structure of Hertugen af Orléans Land, NorthEast Greenland. Rapp. Gronlands geol. Unders. 152, 95-102.

Strachan, R. A., Holdsworth, R. E., Friderichsen, J. D. \& Jepsen, H.F. 1992: Regional Caledonian structure within an oblique convergence zone, Dronning Louise Land, NE Greenland. $J$. geol. Soc. Lond. 149, 359-371.

Sutter, J. F., Zeitler, P. K. \& Tucker, R. D. 1991: Thermochronology: applications to tectonics, petrology, and stratigraphy. U.S. Geol. Surv. Open File Report 91-565, 152 p.

Taylor, S. R. \& McLennan, S. M. 1985: The continental crust: its composition and evolution, 312 pp. Oxford: Blackwell.

Tucker, R.E., Dallmeyer, R.D. \& Strachan, R. A. 1993: Age and tectonothermal record of Laurentian basement, NorthEast Greenland Caledonides. J. geol. Soc. Lond. 150, 371379.

Wright, A.E., Tarney, J., Palmer, K. F., Moorlock, B.S.P. \& Skinner, A.C. 1973: The geology of the Angmagssalik area, East Greenland and possible relations with the Lewisian of Scotland. In Park, R. G. \& Tarney, J. (ed.) The Early Precambrian of Scotland and related rocks of Greenland, 157177. Univ. of Keele, U.K.

Wyllie, P. J. 1957: A geological reconnaissance through South Germania Land, Northeast Greenland, lat. $77^{\circ} \mathrm{N}$, long. $18^{1 / 2^{\circ}} \mathrm{W}$ to $22^{\circ} \mathrm{W}$. Meddr Gronland $157(1), 66 \mathrm{pp}$. 